\title{
Miloslav SPURNÝ*, Miluše VÍTEČKOVÁ*** \\ ROBUSTNESS OF CONTROL SYSTEM TUNED BY MULTIPLE DOMINANT POLE METHOD AND DESIRED MODEL METHOD
}

\author{
ROBUSTNOST REGULAČNÍHO OBVODU SEŘÍZENÉHO MEDOTOU NÁSOBNÉHO \\ DOMINANTNÍHO PÓLU A METODOU POŽADOVANÉHO MODELU
}

\begin{abstract}
In the article two analytical analog controller PI tuning methods are shortly described and compared from the point of view of the control system robustness for the first order plus time delay plant. For comparison the multiple dominant pole method and the desired model method were chosen. The program Matlab/Simulink for verification of the control system robustness was used.
\end{abstract}

Abstrakt

V př́íspěvku jsou stručně popsány a porovnány z hlediska robustnosti regulačního obvodu dvě analytické metody seřízení regulátoru PI pro proporcionální soustavu se setrvačností prvního řádu a dopravním zpožděním. Pro porovnání byla vybrána metoda násobného dominantního pólu a metoda požadovaného modelu. Pro ověření robustnosti byl použit program Matlab/Simulink.

\section{CONTROL OF FOPTD PLANTS}

Consider the control system in Fig. 1 with the first order plus time delay (FOPTD) plant

$$
G_{S} \subsetneq \frac{k_{1}}{T_{1} s+1} \mathrm{e}^{-T_{d 1} s}
$$

and with the PI controller

$$
G_{R} \lessdot k_{P}\left(1+\frac{1}{T_{I} s}\right)
$$

where $k_{1}$ is the plant gain, $T_{1}$ - the time constant, $T_{d 1}$ - the time delay, $k_{P}$ - the controller gain, $T_{I}-$ the integral time, $W(s)$ - the desired variable transform, $V(s)$ - the disturbance variable transform, $Y(s)$ - the controlled variable transform.

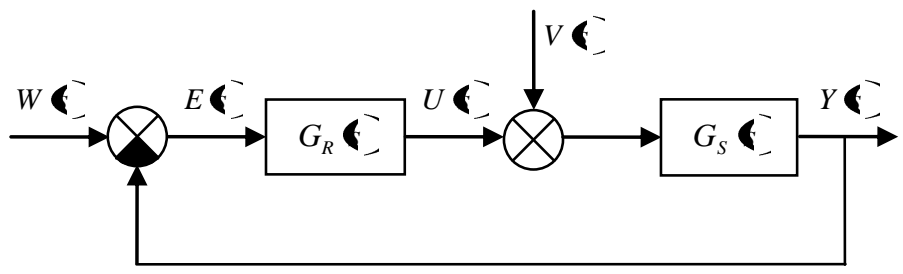

Fig. 1 Control system.

\footnotetext{
Ing. Miloslav SPURNÝ, VŠB - Technical University of Ostrava, Faculty of Mechanical Engineering, Department ATř-352, 17. listopadu 15, Ostrava - Poruba, 708 33, Czech Republic, (+420) 597324118 , e-mail miloslav.spurny@vsb.cz

** Prof. Ing. Miluše VÍTEČKOVÁ, CSc., VŠB - Technical University of Ostrava, Faculty of Mechanical Engineering, Department ATŘ-352, 17. listopadu 15, Ostrava - Poruba, 708 33, Czech Republic, (+420) 59732 4493, e-mail miluse.viteckova@ vsb.cz
} 


\subsection{Multiple dominant pole method}

The multiple dominant pole method (MDPM) is simple analytical tuning method, which ensures the non-oscillating control process $[2,5,9]$. It supposes that the multiple dominant pole determines the control system behavior and influence of the nondominant poles and zeros can be neglected. The triple dominant pole $s_{3}{ }^{*}$ and the adjustable controller parameters $k_{P}{ }^{*}$ a $T_{I}{ }^{*}$ (Tab. 1) can be obtained by solving of the system of three equations

$\frac{\mathrm{d}^{i} N(s)}{\mathrm{d} s^{i}}=0, \quad i=0,1,2$

where $N(s)$ is the characteristic quasi polynomial of the control system with the controller (2) and the plant (1).

The controller adjustable parameters are given in Tab. 1. The MDPM is in detail described e.g. $[2,9]$.

Tab. 1 Adjustable parameters of controller PI for MDPM.

\begin{tabular}{|c|}
\hline The adjustable parameters of controller PI \\
\hline$s_{3}^{*}=-\frac{2}{T_{d 1}}-\frac{1}{2 T_{1}}+\sqrt{\frac{2}{T_{d 1}^{2}}+\frac{1}{4 T_{1}^{2}}}$ \\
\hline$k_{P}^{*}=-\frac{1}{k_{1}} T_{d 1} T_{1} s_{3}^{* 2}+\left(2 T_{1}+T_{d 1}\right) s_{3}^{*}+1 \S^{T_{d 1} s_{3}^{*}}$ \\
$T_{I}^{*}=-\frac{T_{d 1} T_{1} s_{3}^{* 2}+\left(2 T_{1}+T_{d 1}\right) s_{3}^{*}+1}{s_{3}^{* 2}\left(T_{d 1} T_{1} s_{3}^{*}+T_{1}+T_{d 1}\right)}$ \\
\hline
\end{tabular}

\subsection{Desired model method}

The desired model method (DMM) is more general method then it is mentioned here [5, 7 - 9]. In the article it is supposed its use only for the FOPTD plant (1) and for ensuring the nonoscillating control process without overshoot. It is the compensation method and therefore the integral time can be determined from the compensation condition $T_{I}^{*}=T_{1}$. The double pole $s_{2}{ }^{*}=-1 / T_{d 1}$ and the controller gain $k_{P}{ }^{*}=T_{1} /\left(k_{1} \mathrm{e} T_{d 1}\right)$ can be obtained from (3) for $i=0,1$, i.e. from the system of two equations, where $N(s)$ is the characteristic quasi polynomial of the control system in Fig. 1 with the plant (1) and the controller (2) for $T_{I}^{*}=T_{1}$.

Tab. 2 Adjustable parameters of controller PI for DMM.

\begin{tabular}{|c|c|}
\hline \multicolumn{2}{|c|}{ The adjustable parameters of controller PI } \\
\hline$k_{P}^{*}=\frac{T_{1}}{k_{1} \mathrm{e} T_{d 1}}$ & $T_{I}^{*}=T_{1}$ \\
\hline
\end{tabular}

The controller adjustable parameters are given in Tab. 2. The DMM is in detail described e.g. $[7,8]$.

\section{VERIFICATION OF ROBUSTNESS}

For verification of both tuning methods the FOPTD plant was chosen

$$
G_{S}(s)=\frac{0.5}{2.25 s+1} \mathrm{e}^{-9.5 s} \quad \hat{k}_{1}=0.5, \quad \hat{T}_{1}=2.25 \mathrm{~s}, \quad \hat{T}_{d 1}=9.5 \mathrm{~s}
$$

where the symbol $^{\wedge}$ means nominal value. 
The changes of nominal values of parameters $\hat{k}_{1}, \hat{T}_{1}$ and $\hat{T}_{d 1}$ of the FOPTD plant were being considered $\pm 25 \%$ :

$$
\begin{aligned}
k_{1} & =\delta \hat{k}_{1} \\
T_{1} & =\delta \hat{T}_{1} \\
T_{d 1} & =\delta \hat{T}_{d 1}
\end{aligned}
$$

where $\delta=0.75,1$ and 1.25 .

The influence of the changes of the plant parameters $k_{1}, T_{1}$ and $T_{d 1}(5)$ was examined by the help of the simulation program Matlab/Simulink.

\subsection{Multiple dominant pole method}

On the basis of Tab. 1 for the MDPM the PI controller parameters were obtained $s_{3}^{*}=-0.165$

$$
k_{P}^{*}=0.304 \quad T_{I}^{*}=3.252 \mathrm{~s}
$$

By means of the computer and the program Matlab/Simulink the control system responses were obtained (Figs $2-5$ ). The Figs 2, 3 and 4 show the control system responses successively for $\pm 25 \%$ changes of the plant gain $k_{1}$, the time constant $T_{1}$ and the time delay $T_{d}$. Fig. 5 shows the hardest case of simultaneous changes of all plant parameters $\pm 25 \%$.

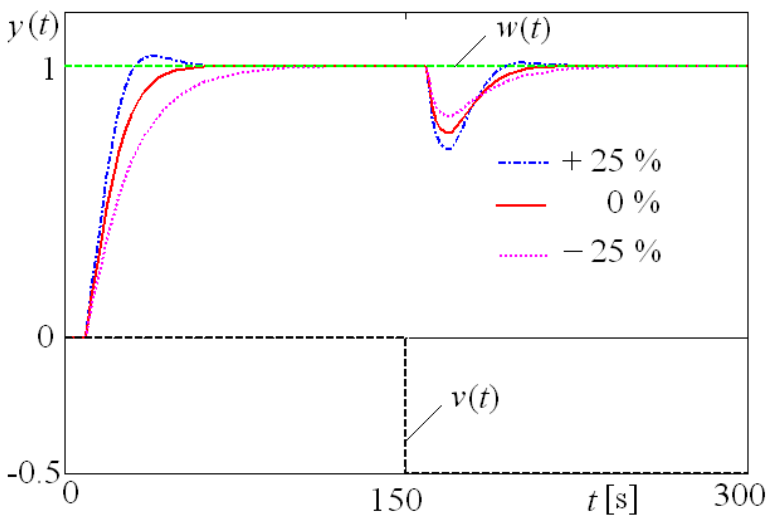

Fig. 2 Control system responses for changes of plant gain $k_{1}(\mathrm{MDPM})$.

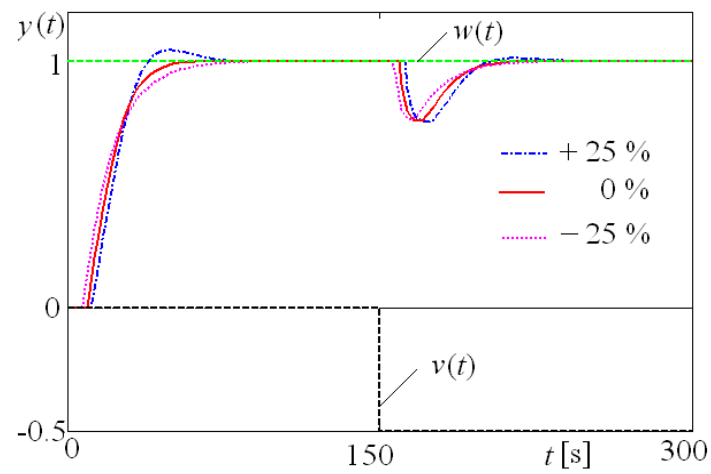

Fig. 4 Control system responses for changes of plant time delay $T_{d 1}(\mathrm{MDPM})$.

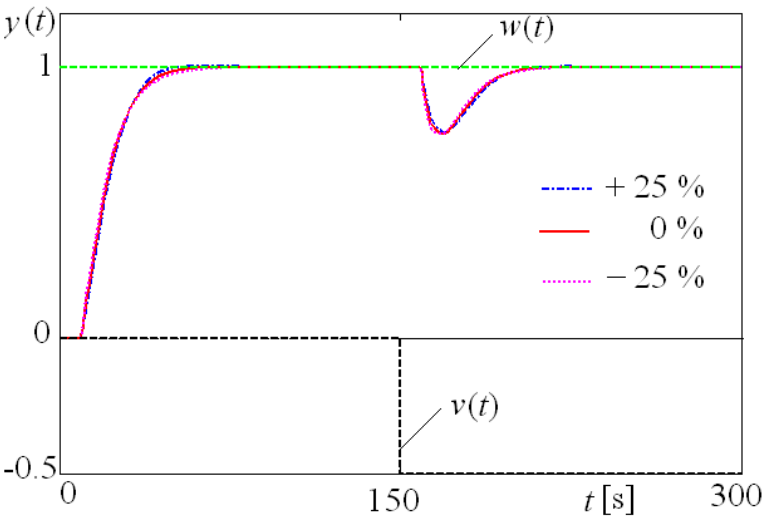

Fig. 3 Control system responses for changes of plant time constant $T_{1}(\mathrm{MDPM})$.

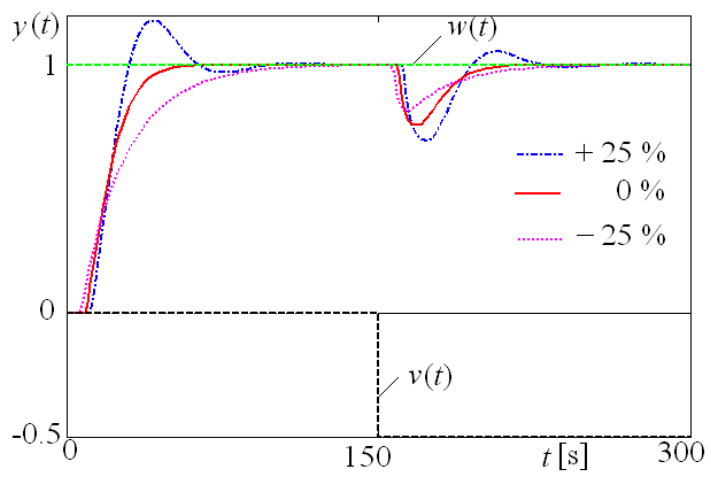

Fig. 5 Control system responses for changes of all plant parameters $k_{1}, T_{1}$ and $T_{d 1}$ (MDPM). 
On the basis of the control system responses in Figs $2-5$ it is possible to say, that the control system tuned by the MDPM is robust. The change of the plant gain $k_{1}$ has the highest influence on the control system responses.

\subsection{Desired model method}

The adjustable controller parameters for the DMM were computed in accordance with Tab. 2 $k_{P}^{*}=0.174$

$$
T_{I}^{*}=2.250 \mathrm{~s} \text {. }
$$

The responses of the control system tuned by the DMM are in Figs $6-9$. The obtained courses are similar to the previous courses obtained by the MDPM and therefore the conclusions are the same.

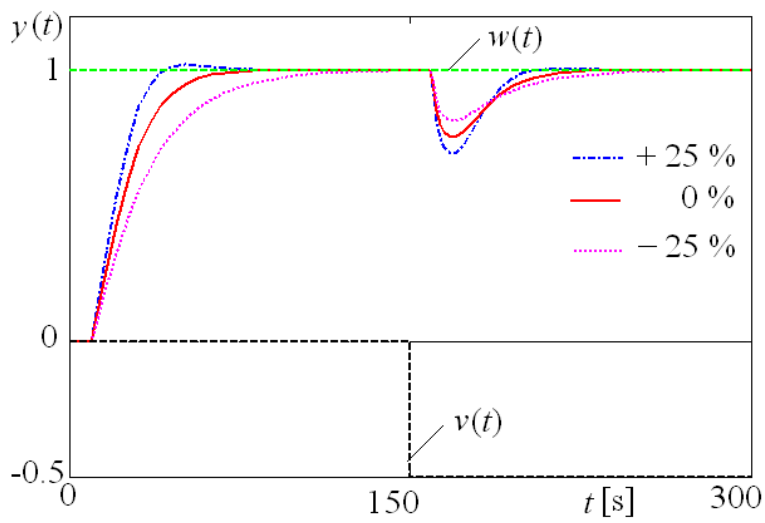

Fig. 6 Control system responses for changes of plant gain $k_{1}(\mathrm{DMM})$.

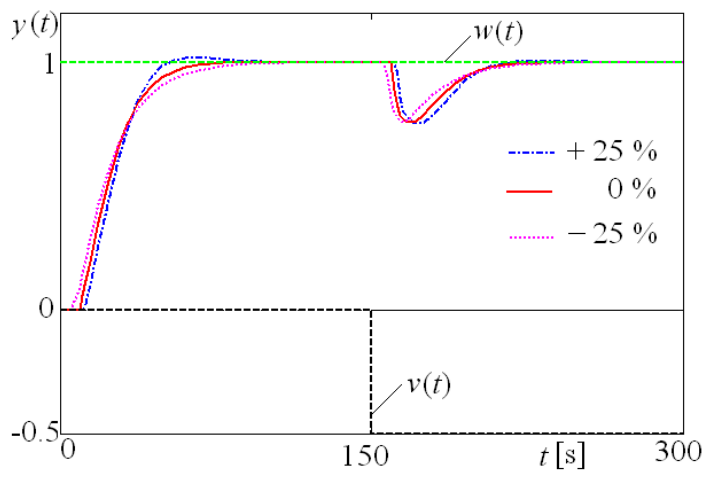

Fig. 8 Control system responses for changes of plant time delay $T_{d 1}(\mathrm{DMM})$.

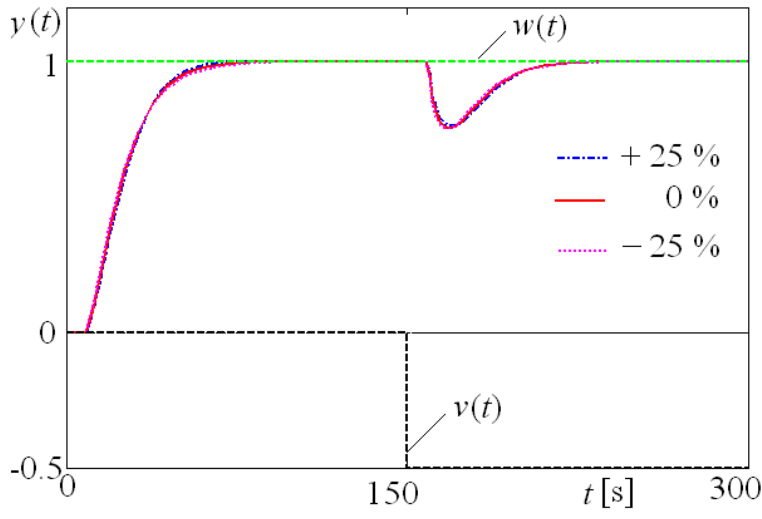

Fig. 7 Control system responses for changes of plant time constant $T_{1}(\mathrm{DMM})$.

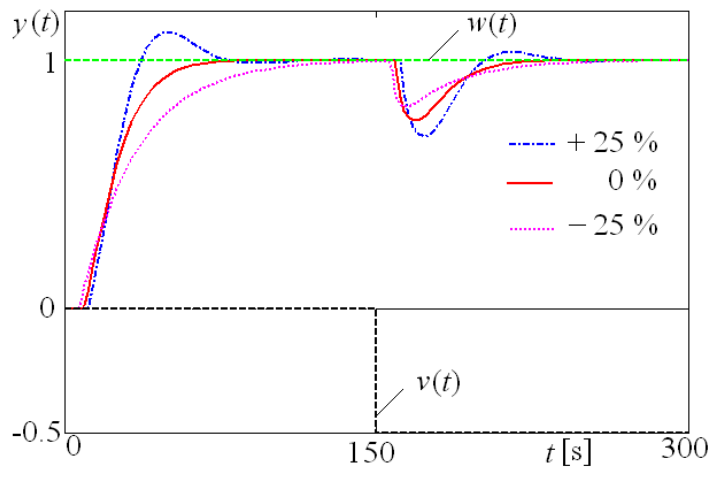

Fig. 9 Control system responses for changes of all plant parameters $k_{1}, T_{1}$ and $T_{d 1}(\mathrm{DMM})$.

The two performance indices - the settling time $(5 \%)$ and the criterion ITAE (integral of time multiplied by absolute error) for both methods were determined $[1,4,6]$. The obtained performance index values are given in Tab. 3. In accordance with expectation the performance indices for the MDPM are better then for the DMM. Both described methods are rather robust. The control system tuned by the MDPM has the triple dominant pole while the control system tuned by the DMM has only the double dominant pole and therefore the first method must give faster responses. 
Tab. 3 Control process performance indices for MDPM and DMM.

\begin{tabular}{|c|c|c|c|c|c|c|}
\hline & \multicolumn{2}{|c|}{ Multiple dominant pole method } & \multicolumn{3}{c|}{ Desired model method } \\
\hline $\begin{array}{c}\text { Control } \\
\text { process per- } \\
\text { formance } \\
\text { index }\end{array}$ & $\begin{array}{c}\text { Change of } \\
\text { all parame- } \\
\text { ters }-25 \%\end{array}$ & $\begin{array}{c}\text { Nominal } \\
\text { parameters }\end{array}$ & $\begin{array}{c}\text { Change of } \\
\text { all parame- } \\
\text { ters }+25 \%\end{array}$ & $\begin{array}{c}\text { Change of } \\
\text { all parame- } \\
\text { ters }-25 \%\end{array}$ & $\begin{array}{c}\text { Nominal } \\
\text { parameters }\end{array}$ & $\begin{array}{c}\text { Change of } \\
\text { all parame- } \\
\text { ters }+25 \%\end{array}$ \\
\hline $\begin{array}{c}\text { Settling time } \\
t_{r}[\mathrm{~s}]\end{array}$ & 73.22 & 40.45 & 57.33 & 88.55 & 51.78 & 65.23 \\
\hline Criterion ITAE & 656.03 & 276.09 & 439.58 & 958.29 & 420.65 & 469.21 \\
\hline
\end{tabular}

\section{CONCLUSION}

In the article the robustness of the MDPM and DMM for the PI analog controller and the FOPTD plant had been verified. The both methods are robust. The MDPM gives better values of the performance indices then the DMM but the DMM is simpler. For both methods changes of the plant gains have the highest influence on the control process and changes of the time constants have the lowest influence.

This work was supported by research project GACR No 102/09/0894 and project SP 2011/18.

\section{REFERENCES}

[1] ÅSTRÖM K. J. \& HÄGGLUND, T. Advanced PID Control. Research Triangle Park: ISA The Instrumentation, Systems, and Society, 460 pp, 2006.

[2] GÓRECKI, H. Analysis and Synthesis of Control Systems with Time Delay (in Polish). Warszawa: Wydawnictwo Naukowo - Techniczne, 372 pp., 1971.

[3] KUKAL, J. Robustnost. Automatizace, Volume 51, 9/ 2008, pp. 570 - 572.

[4] O'DWYER, A. Handbook of PI and PID Controller Tuning Rules. $3^{\text {rd }}$ Edition. London: Imperial College Press, 608 pp., 2009.

[5] SPURNÝ, M. Metoda násobného dominantního pólu. Diplomová práce (školitel: Prof. Ing. Miluše Vítečková, CSc.), Fakulta strojní, VŠB-TU Ostrava.

[6] VISIOLI, A. Practical PID Control. London: Springer-Verlag, 310 pp., 2006.

[7] VÍTEČKOVÁ, M. Seřizení regulátorů metodou inverse dynamiky. Ostrava: VŠB-TU Ostrava, Fakulta strojní, 56 s., 1998.

[8] VÍTEČKOVÁ, M. Digital and Analog Controller Tuning for Processes with Time Delay (in Czech). Automatizace, Volume 42, 2/1999, pp. 106 - 111.

[9] VÍTEČKOVÁ, M., VÍTEČEK, A. Základy automatické regulace. 2. vyd. Ostrava: VŠB-TU Ostrava, Fakulta strojní, 243 s., 2008. 
